\title{
Element of integrated pest management of tomato in the field, against the early and late blight with the use of natural products
}

\author{
Element integrowanej ochrony pomidora w uprawie polowej \\ przed zarazą ziemniaka i alternariozą z wykorzystaniem środków \\ pochodzenia naturalnego
}

Jan Sobolewski, Józef Robak, Agnieszka Czajka

\section{Summary}

Due to the current system of integrated cultivation of tomato since 2014, the program was verified to protect tomato against the most dangerous diseases. The aim of the research conducted in the years 2012 and 2013 was to assess the effectiveness of natural products and Bacillus subtilis to protected tomato against late blight and early blight in the prevention system. The reference product was a fungicide containing a mixture of boscalid and pyraclostrobin. Tea tree oil and extract of berries showed good efficacy in the protection of tomato against potato early blight and late blight. A mixture of boscalid and pyraclostrobin showed higher efficacy in reducing the development of these diseases. There were no effects of phytotoxicity. All the tested products increased the yield of tomatoes.

Key words: early blight; late blight; natural products; Bacillus subtilis; protect of tomato

\section{Streszczenie}

Dokonano weryfikacji programu ochrony pomidora przed najgroźniejszymi chorobami, ze względu na obowiązujący system integrowanej uprawy pomidora od roku 2014. Celem badań prowadzonych w latach 2012 i 2013 była ocena skuteczności środków naturalnych $\mathrm{i}$ bakterii Bacillus subtilis $\mathrm{w}$ ochronie pomidora przed zarazą ziemniaka $\mathrm{i}$ alternariozą w systemie zapobiegawczym. Środkiem referencyjnym był fungicyd zawierający mieszaninę boskalidu i piraklostrobiny. W ochronie pomidora przed zarazą ziemniaka i alternariozą dobrą skuteczność wykazał olej melaleuca i wyciąg z owoców jagodowych. Wyższą skuteczność w ograniczaniu rozwoju tych chorób wykazała mieszanina boskalidu i piraklostrobiny. Nie obserwowano efektów fitotoksyczności. Wszystkie badane środki spowodowały wzrost plonowania pomidorów.

Słowa kluczowe: alternarioza; zaraza ziemniaka; środki naturalne; Bacillus subtilis; ochrona pomidora 


\section{Wstęp / Introduction}

W produkcji pomidora $\mathrm{W}$ uprawie polowej duży problem gospodarczy stanowią dwie choroby - zaraza ziemniaka i alternarioza (Sherf i wsp. 1986; Robak i wsp. 2012). System ochrony pomidora w głównej mierze oparty jest na programach stosowania konwencjonalnych fungicydów chemicznych (Pruszyński i wsp. 2008). Z uwagi na obowiązujący system integrowanej uprawy pomidora od roku 2014 (MRiRW 2013), podjęto weryfikację obecnego programu zwalczania tych chorób w uprawie pomidora, wprowadzając jako jeden z elementów możliwość wykorzystania środków pochodzenia naturalnego (Matyjaszczyk 2009) oraz bakterii z rodzaju Bacillus (Czaczyk i wsp. 2001; Stachowiak 2007). W ochronie wielu gatunków roślin warzywnych podejmuje się badania nad wykorzystaniem środków pochodzenia naturalnego (Robak i wsp. 2012). Także wykorzystywanie antagonistycznych bakterii w stosunku do niektórych gatunków grzybów jest coraz bardziej powszechne (Sadowska i wsp. 2011). Ratajkiewicz i wsp. (2008) wykazali antagonistyczny wpływ Bacillus coagulans (Hammer) w stosunku do wielu gatunków patogenicznych grzybów i organizmów grzybopodobnych, w tym Alternaria alternata (Fr.) Keissl. Ochrona pomidorów przed zarazą ziemniaka i alternariozą wymaga weryfikacji w kontekście wprowadzenia obok fungicydów konwencjonalnych, także środków pochodzenia naturalnego i antagonistycznych organizmów żywych stosowanych zapobiegawczo. Fungicydy o właściwościach zapobiegawczych i leczniczych są zarejestrowane w wielu krajach do stosowania w ochronie pomidorów i ziemniaków przed alternariozą (Madden i wsp. 1978). W Polsce do ochrony pomidora $\mathrm{w}$ uprawie polowej przed alternariozą i zarazą ziemniaka dopuszczone są liczne konwencjonalne fungicydy. Brak jest środków pochodzenia innych, niż chemiczne do ochrony przed tymi chorobami.

Wobec powyższego podjęto badania nad oceną wybranych środków pochodzenia naturalnego, a także antagonistycznego organizmu żywego w ograniczaniu Phytophthora infestans (Mont.) de Bary i Alternaria solani Sorauer, w uprawie pomidora. Badania prowadzono w Instytucie Ogrodnictwa w Skierniewicach w latach 2012-2013.

Do testów przyjęto następujące środki: zawierający antagonistyczny gatunek bakterii $B$. subtilis, wyciąg z owoców jagodowych, olej melaleuca oraz chitozan. Według Kouyoumjian (2007), B. subtilis korzystnie wpływał na ograniczenie nasilenia alternariozy w uprawie pomidorów w początkowym okresie zagrożenia tą chorobą. Właściwości ekstraktów z nasion roślin jagodowych są znane w badaniach z zakresu medycyny (Sala i wsp. 2003). Wyciąg z owoców jagodowych i olej melaleuca wykazał wysoką skuteczność w ograniczaniu grzyba z rodzaju Alternaria w uprawie kapusty pekińskiej (Robak i wsp. 2012). Według Abbo i wsp. (2009) Timorex Gold 24 EC zawierający olej melaleuca powodował ograniczenie Alternaria spp. na pomidorze.

\section{Materiały i metody / Materials and methods}

W latach 2012 i 2013 realizowano doświadczenia polowe w układzie losowanych bloków w 4 powtórzeniach, zgodnie z Dobrą Praktyką Ochrony Roślin (Pruszyński i Wolny 2007). Powierzchnia poletka wynosiła 2,5 $\mathrm{m}^{2}$ (EPPO PP/1/65(3)). Rośliny pomidora odmiany Rumba inokulowano metodą opryskiwania zawiesiną zarodników konidialnych A. solani o zagęszczeniu $10^{4} \mathrm{cpu} / \mathrm{ml}$. Namnażanie patogena realizowano w szalkach o średnicy $9 \mathrm{~cm}$ na pożywce LBA (lima been agar) utrzymywanej w temperaturze $23^{\circ} \mathrm{C}$. Zawiesinę konidiów zebrano z kultur przez ich spłukiwnie wodą destylowaną po 30 godzinach hodowli (Vloutoglou i Kalogeriakis 2000; Khan 2002). W przypadku P. infestans inokulum stanowiły sporangia pobierane $\mathrm{z}$ zakażonych roślin pomidora $\mathrm{w}$ fazie BBCH 19, rosnących w fitotronie, w warunkach wilgotności względnej powietrza $98 \%$ i przy temperaturze $24^{\circ} \mathrm{C}$ w cyklu dziennym i $18^{\circ} \mathrm{C}$ w cyklu nocnym. Inokulację pomidorów izolatem $P$. infestans dokonano przez opryskiwanie ich zawiesiną sporangiów o koncentracji $50000 \mathrm{cpu} \mathrm{w} 1 \mathrm{ml}$. Następnie po inokulacji rośliny okryto tunelem foliowym, aby zwiększyć wilgotność powietrza do 100\% (Merk i Foolad 2012). Inkubacja trwała przez $7 \mathrm{dni} w$ temperaturze $15-16^{\circ} \mathrm{C}$, przy stałym oświetleniu około 1600 lx (Lebecka 2007). Zawiesina sporangiów była przetrzymywana przez 90 minut $\mathrm{w}$ temperaturze $4^{\circ} \mathrm{C}$, następnie przez 30 minut w $20^{\circ} \mathrm{C}$ (Bartkowska i Weber 2006).

Inokulację pomidorów realizowano w doświadczeniu nr 1 dnia 14.08.2012 w stadium BBCH 71, zaś w doświadczeniu 2. przeprowadzono w dniu 21.08.2013 w stadium roślin BBCH 72. Ochronę pomidorów przed alternariozą i zarazą ziemniaka prowadzono w systemie zapobiegawczym. Pierwszy zabieg badanymi środkami był wykonany jeden dzień przed inokulacją roślin, a kolejne 3 zabiegi realizowano co 10 dni. Zabiegi wykonywano za pomocą opryskiwacza poletkowego, stosując dawkę cieczy roboczej 500 1/ha. Ocenę porażenia powierzchni liści i owoców przez A. solani i P. infestans przeprowadzono według skali: $0^{\circ}$ - brak objawów, $7^{\circ}-100 \%$ porażenia (Sobolewski i wsp. 2006). Wpływ fitotoksyczności szacowano według skali $0^{\circ}$ - brak objawów, $5^{\circ}$ - bardzo silne uszkodzenia roślin [EPPO PP/1/65(3)].

Badany referencyjny środek pochodzenia handlowego był mieszaniną boskalidu o zawartości $26,7 \%$ i piraklostrobiny o zawartości 6,7\%. Testowane środki handlowe pochodzenia naturalnego zawierały: antagonistyczną bakterię B. subtilis o zawartości 1,34\% w produkcie, olej melaleuca występujący w ilości $23,8 \%$ w produkcie i chitozan o zawartości $20 \mathrm{~g} / \mathrm{l} \mathrm{w}$ środku. Środki te były produktami handlowymi. Badano także ekstrakt $\mathrm{z}$ owoców jagodowych uzyskany $\mathrm{z}$ nasion truskawki, zawierający naturalne polifenole, w ilości $50 \mathrm{~g} / \mathrm{l}$, który pochodził z Zakładu Analizy i Technologii Politechniki Łódzkiej. Wyniki opracowano za pomocą analizy wariancji, istotność różnic oceniono testem Newmana-Keulsa. 


\section{Wyniki i dyskusja / Results and discussion}

Integrowana ochrona roślin wymaga ograniczenia zakresu stosowania chemicznych środków ochrony roślin. To stwarza konieczność do podejmowania badań i wdrażania do praktyk ogrodniczych metod biologicznych W oparciu o środki pochodzenia naturalnego (Lipa i Pruszyński 2010). W badaniach prowadzonych w Instytucie Ogrodnictwa jednym z zagadnień w tym zakresie było opracowanie metody ochrony pomidora w uprawie polowej przed najgroźniejszymi chorobami z wykorzystaniem środków pochodzenia naturalnego, przyjaznych dla środowiska. Ponadto narastający proces odporności niektórych populacji agrofagów na stosowane fungicydy wymaga wprowadzenia do programu sekwencyjnego ich stosowania, także środków o odmiennym mechanizmie aktywności antagonistycznej w stosunku do patogenów (Zamojska i Malinowski 2012).

Kryterium wyboru środków do badań stanowiła ich dostępność, a także charakterystyka biologicznej aktywności w stosunku do $P$. infestans i $A$. solani.

Najwyższą skuteczność w ochronie pomidora przed zarazą ziemniaka uzyskano po stosowaniu mieszaniny boskalidu i piraklostrobiny aplikowanych 4 razy w odstępach co 10 dni. Olej melaleuca, ekstrakt z owoców jagodowych oraz chitozan wykazał dobrą skuteczność w ochronie pomidora przed P. infestans i Alternaria spp., jednak istotnie niższą w stosunku do mieszaniny boskalidu i piraklostrobiny. Znane są przypadki, że naturalne ekstrakty zawierające lotne związki wykazują nieraz podobną aktywność w ograniczaniu rozwoju wielu gatunków bakterii lub grzybów w stosunku do działania środków chemicznych (Bakali i wsp. 2008). Jak donosi Kowalska (2012) istnieje możliwość ograniczania $P$. infestans stosując grzyb Trichoderma asperellum w formie doglebowej aplikacji oraz zabiegów opryskiwania nalistnego. Także gatunek grzyba Saccharomyces cerevisiae ograniczał $P$. infestans (Kowalska 2013).

W pierwszym cyklu badań z zastosowaniem B. subtilis uzyskano niższą skuteczność ograniczania $P$. infestans w stosunku do wyników w roku następnym. Podobny efekt zróżnicowania skuteczności w dwóch różnych cyklach doświadczalnych wykazał Ratajkiewicz i wsp. (2011) badając wpływ szczepów bakterii z rodzaju Bacillus w ograniczaniu $A$. radicina na korzeniach marchwi. Analizując skuteczność środków naturalnych, najmniej objawów zarazy ziemniaka notowano na roślinach traktowanych środkami zawierającymi olej melaleuca i wyciąg z owoców jagodowych. W ochronie pomidorów przed alternariozą mieszanina boskalidu i piraklostrobiny także wykazała wysoką skuteczność, porównywalną ze skutecznością oleju melaleuca i ekstraktu z owoców jagodowych, gdzie uzyskano w dwóch cyklach doświadczalnych od 0,9 do $0,4 \%$ porażonej powierzchni

Tabela 1. Ocena biologicznej skuteczności fungicydów w ochronie pomidora przed alternariozą (A. solani) i zarazą ziemniaka (P. infestans) w uprawie polowej

Table 1. Evaluation of the biological efficacy of fungicides in the protection of tomato against early blight (A. solani) and late blight (P. infestans) in the field

Doświadczenie nr 1 i 2 - Experiment No. 1 and 2 Skierniewice 2012-2103

\begin{tabular}{|c|c|c|c|c|c|c|c|c|c|}
\hline \multirow{3}{*}{$\begin{array}{l}\text { Substancja czynna } \\
\text { Active substances }\end{array}$} & \multirow{3}{*}{$\begin{array}{c}\text { Dawka } \\
\text { Dose } \\
\text { [g/ha] }\end{array}$} & \multicolumn{4}{|c|}{$\begin{array}{l}\text { Procent porażonej } \\
\text { powierzchni rośliny } \\
\text { Percent of infected } \\
\text { plant surface }\end{array}$} & \multicolumn{4}{|c|}{$\begin{array}{l}\text { Plon handlowy } \\
\text { Marketable yield }\end{array}$} \\
\hline & & \multicolumn{2}{|c|}{ P. infestans } & \multicolumn{2}{|c|}{ A. solani } & \multicolumn{2}{|c|}{$\left[\mathrm{kg} / 10 \mathrm{~m}^{2}\right]$} & \multicolumn{2}{|c|}{$\begin{array}{c}\text { Zwyżka } \\
\text { increase } \\
{[\%]}\end{array}$} \\
\hline & & $\begin{array}{l}\text { rok } \\
\text { year } \\
2012\end{array}$ & $\begin{array}{l}\text { rok } \\
\text { year } \\
2013\end{array}$ & $\begin{array}{c}\text { rok } \\
\text { year } \\
2012\end{array}$ & $\begin{array}{c}\text { rok } \\
\text { year } \\
2013\end{array}$ & $\begin{array}{l}\text { rok } \\
\text { year } \\
2012\end{array}$ & $\begin{array}{c}\text { rok } \\
\text { year } \\
2013\end{array}$ & $\begin{array}{c}\text { rok } \\
\text { year } \\
2012\end{array}$ & $\begin{array}{l}\text { rok } \\
\text { year } \\
2013\end{array}$ \\
\hline $\begin{array}{l}\text { Kontrola } \\
\text { Untreated }\end{array}$ & - & $17,0 \mathrm{a}$ & $6,4 \mathrm{a}$ & $9,2 \mathrm{a}$ & $8,1 \mathrm{a}$ & $15,8 \mathrm{c}$ & $14,3 \mathrm{f}$ & 100 & 100 \\
\hline Bacillus subtilis & 0,011 & $14,8 \mathrm{~b}$ & $3,4 \mathrm{bc}$ & $3,6 \mathrm{~b}$ & $2,4 \mathrm{~b}$ & $20,1 \mathrm{~b}$ & $29,8 \mathrm{c}$ & 127 & 208 \\
\hline B. subtilis & 0,022 & $12,4 \mathrm{c}$ & $2,8 \mathrm{~cd}$ & $2,2 \mathrm{c}$ & $1,6 \mathrm{c}$ & $21,1 \mathrm{~b}$ & $29,9 \mathrm{~b}$ & 133 & 209 \\
\hline $\begin{array}{l}\text { Olej melaleuca } \\
\text { Oil melaleuca }\end{array}$ & 0,1785 & $5,0 \mathrm{e}$ & $2,9 \mathrm{~cd}$ & $0,9 \mathrm{~d}$ & $0,5 \mathrm{~d}$ & $22,2 \mathrm{~b}$ & $23,1 \mathrm{~d}$ & 140 & 161 \\
\hline $\begin{array}{l}\text { Ekstrakt z truskawki } \\
\text { Strawberry extract }\end{array}$ & 0,5 & $6,2 \mathrm{de}$ & $3,2 \mathrm{bc}$ & $0,7 \mathrm{~d}$ & $0,5 \mathrm{~d}$ & $22,3 \mathrm{~b}$ & $28,4 \mathrm{~d}$ & 141 & 198 \\
\hline $\begin{array}{l}\text { Chitozan } \\
\text { Chitosan }\end{array}$ & 0,4 & $7,8 \mathrm{~d}$ & $8,7 \mathrm{c}$ & $0,9 \mathrm{~d}$ & $0,4 \mathrm{~d}$ & $22,2 \mathrm{~b}$ & $26,7 \mathrm{~d}$ & 140 & 186 \\
\hline Piraclostrobin + boskalid & $\begin{array}{l}0,01 \\
0,04\end{array}$ & $0,4 \mathrm{f}$ & $0,3 \mathrm{e}$ & $0,9 \mathrm{~d}$ & $0.5 \mathrm{~d}$ & 26,4 a & 33,6 a & 167 & 235 \\
\hline $\operatorname{NIR}(0,05)-\operatorname{LSD}(0.05)$ & & 1,67 & 0,70 & 0,62 & 0,21 & 0,41 & 0,44 & - & \\
\hline
\end{tabular}

Wartości liczbowe w kolumnach oznaczone tą samą literą nie różnią się istotnie przy p = 0,05

Newman-Keul's test; the mean numbers with the same letter are not significantly different at $\mathrm{p}=0.05$ 
rośliny. Wymienione badane środki istotnie wpłynęły na zwiększenie plonu owoców w stosunku do roślin nietraktowanych. Nie obserwowano efektów fitotoksyczności badanych fungicydów na traktowanych roślinach. Podobne wyniki $\mathrm{z}$ pozytywnym skutecznością oleju melaeuca $\mathrm{w}$ ochronie pomidorów przed alternariozą wykazał Abbo i wsp. (2009).

\section{Wnioski / Conclusions}

1. Środki pochodzenia naturalnego: olej melaleuca, ekstrakt $\mathrm{z}$ truskawki i chitosan oraz mieszanina boskalidu i piraklostrobiny wpłynęły na zmniejszenie występowania objawów alternariozy. Nie wykazano istotnych różnic w skuteczności badanych środków.

2. W ochronie pomidora przed zarazą ziemniaka spośród badanych środków pochodzenia naturalnego wysoką skuteczność wykazał olej melaleuca i ekstrakt z owoców jagodowych. W roku 2012 uzyskano odpowiednio 5,0 i 6,2, zaś w kolejnym roku 2,9 i 3,2 procent porażenia powierzchni rośliny. Skuteczność była istotnie niższa $\mathrm{w}$ stosunku do mieszaniny boskalidu i pyraklostrobiny.

3. Badane środki naturalne: ekstrakt $\mathrm{z}$ owoców jagodowych, olej melaleuca i chitozan oraz bakteria $B$. subtilis wykazały wyższą skuteczność $\mathrm{w}$ ochronie pomidora przed alternariozą, mniejszą w przypadku zwalczania zarazy ziemniaka.

4. Doskonalenie systemu integrowanej ochrony pomidorów przez zarazą ziemniaka i alternariozą wymaga dalszych badań, ze szczególnym uwzględnieniem ekstraktu $\mathrm{z}$ owoców jagodowych, nowego związku pochodzenia naturalnego.

Praca została wykonana w ramach Programu Wieloletniego „Rozwój zrównoważonych metod produkcji ogrodniczej w celu zapewnienia wysokiej jakości biologicznej i odżywczej produktów ogrodniczych oraz zachowania bioróżnorodności środowiska i ochrony jego zasobów", finansowanego przez Ministerstwo Rolnictwa i Rozwoju Wsi.

\section{Literatura / References}

Abbo A.S.H., Idris M.O., ElBalla M.M.A. 2009. The response of tea tree oil as a biofungicide against early blight disease in tomato crop (Solanum lycopersicum) in Sudan. Conference on International Research on Food Security. Natural Resouece Managament and Rural Development. University of Hamburg, October 6-8, 2009. http://www.tropentag.de/2009/abstracts/ full/691.pdf [Accessed: 02.04.2014]

Bakkali F., Averbeck S., Averbeck D., Idaomar M. 2008. Biological effects of essential oils-A review. Food Chem. Toxicol. 46: 446-475.

Bartkowiak B., Weber Z. 2006. Charakterystyka izolatów Phytophthora infestans (Mont.) de Bary występujących na pomidorze i wpływ pasażowania na ich chorobotwórczość. [Some characteristics of Phytophthora infestans (Mont.) de Bary isolates occurring on tomato and passage influence on their pathogenicity]. Prog. Plant Prot./Post.Ochr. Roślin 46 (2): 533-537.

Czaczyk K., Stachowiak B., Trojanowska K. 2001. Antifungal activity of Bacillus sp. isolated from compost. Folia Microbiol. 45: $552-554$.

EPPO Standards Vol 2. Fungicides and bacteriocides. (EPPO PP/1/65(3), $197 \mathrm{pp.}$

Khan A.A. 2002. Resistance of two tomato species to five isolates of Alternaria solani. Asian J. Plant Sci. 1 (6): $703-704$.

Kouyoumjian R.E. 2007. Comparison of compost tea and biological fungicides for control of early blight in organic heirloom tomato production. MS Thesis. Clemson University, South Carolina. http://tigerprints.clemson.edu/cgi/viewcontent.cgi?article=1263 \&context=all_theses [Accessed: 02.04.2014].

Kowalska J. 2010. Ochrona upraw ziemniaków w systemie rolnictwa ekologicznego. Poznań 2010. http://www.ior.poznan.pl/plik,539, ochrona-upraw-ziemniakow-w-systemie-rolnictwa-ekologicznego-pdf [dostęp: 07.05.2014].

Kowalska J. 2013. Metody zastąpienia miedzi w ochronie warzyw i ziół uprawianych w rolnictwie ekologicznym. http://www.ior. poznan.pl/plik,1708,sprawozdanie-zamieszczono-14-11-2013.pdf [dostęp: 07.05.2014].

Lebecka R. 2007. Psianka czarna (Solanum nigrum L.) może być gospodarzem dla Phytophthora infestans (Mont) De Bary, sprawcy zarazy ziemniaka. [Black nightshade (Solanum nigrum L.) is a host for a causal agent of potato late blight Phytophthora infestans (Mont) de Bary)]. Prog. Plant Prot./Post. Ochr. Roślin 47 (2): 170-172.

Lipa J., Pruszyński S. 2010. Stan wykorzystania metod biologicznych w ochronie roślin w Polsce i na świecie. [Scale of use of biological methods in plant protection in poland and in the world]. Prog. Plant Prot./Post. Ochr. Roślin 50 (3): 1033-1043.

Madden L., Pennypacker S.P., MacNab A.A. 1978. FAST, a forecast system for Alternaria solani on tomato. Phytopathology 68: $1354-1358$

Matyjaszczyk E. 2009. Konsekwencje zmian na liście środków ochrony roślin dopuszczonych do obrotu i stosowania w Polsce dla wybranych roślin uprawnych. [Current possibilities of selected minor crops protection in Poland and other European Union countries]. Prog. Plant Prot./Post. Ochr. Roślin 49 (2): 492-499.

Matyjaszczyk E. 2012. Aktualne możliwości ochrony wybranych upraw małoobszarowych w Polsce i innych państwach Unii Europejskiej. [Current possibilities of selected minor crops protection in Poland and other European Union countries]. Prog. Plant Prot./Post. Ochr. Roślin 52 (1): 167-173.

Merk H.L., Foolad M.R. 2012. Parent- offspring correlation estimate of heritability for late blight resistance conferred by an accession of the tomato wild species Solanum pimpinellifolium. Plant Breeding 131: 203-210.

MRiRW 2013. Rozporządzenie Ministra Rolnictwa i Rozwoju Wsi z dn. z dnia 8 marca 2013 r. Dz. U. z 2013 r. poz. 455,76 ss.

Pruszyński S., Wolny S. 2007. Przewodnik dobrej praktyki ochrony roślin. Inst. Ochr. Roślin, Poznań, 80 ss.

Pruszyński S., Mrówczyński M., Pruszyński G. 2008. Ochrona roślin w integrowanej technologii produkcji rolniczej. Probl. Inż. Rol. 1: 87-97. 
Robak J., Rogowska M., Anyszka Z. 2012. Integrowana ochrona warzyw w Polsce - aktualny stan badań i wdrożeń. [Integrated pest management of vegetables in Poland - current research and implementation into practice]. Prog. Plant Prot./Post. Ochr. Roślin 52 (4): 1210- 1216.

Sadowska K., Pukacka A., Rataj-Guranowska M. 2011. Aktywność in vitro Bacillus subtilis i Pseudomonas fluorescens w hamowaniu rozwoju grzybów patogenicznych dla roślin bobowatych. [In vitro activity of Bacillus subtilis and Pseudomonas fluorescens in growth inhibition of pathogenic fungi for fabaceae plants]. Prog. Plant Prot./Post. Ochr Roślin 51 (1): 403-405.

Sala A., Recio M.C., Schinella G.R., Máňez S., Giner R.M., Cerdá N., Ríos J.-L. 2003. Assessment of the anti-inflammatory activity and free radical scavenger activity of tiliroside. Eur. J. Pharmacol. 461: 53-61.

Sherf A.F., MacNab A.A. 1986. Vegetable diseases and their control, 2nd ed. John Wiley \& Sons, NY, 728 pp.

Sobolewski J., Robak J., Ostrowska A. 2006. Potencjalne możliwości środków organicznych w ograniczaniu Phytophthora infestans na pomidorach w uprawie polowej i pod osłonami. [Potential possibilities of organic products in suppresing Phytophthora infestans on tomatoes in open field and protected cultivation]. Prog. Plant Prot./Post. Ochr. Roślin 46 (2): 704-707.

Tsror L. 1999. Biological control of early blight in tomatoes. Acta Hortic. 487: 271-273.

Vloutoglou I., Kalogeriakis S.N. 2000. Effect of inoculum concetration, wetness duration and plant age on development of early blight (Alternaria solani) and on shedding of leaves in tomato plants. Plant Pathol. 49: 339-345.

Zamojska J., Malinowski H. 2012. Integrowana metoda ochrony roślin a odporność agrofagów na pestycydy w Polsce. [Integrated plant protection and pest resistance to pesticides in Poland]. Prog. Plant Prot./Post. Ochr. Roślin 52 (4): 1222-1226. 